\title{
Analysis of the Titanium-Zirconia Implant- Abutment Micro-Gaps
}

\author{
${ }^{1}$ Jair Rodríguez-Ivich ${ }^{2}$, Abraão Moratelli Prado ${ }^{3}$, Antônio Carlos Cardoso ${ }^{4}$, Cimara Fortes \\ Ferreira* \\ ${ }^{1}$ Private practice, Pegaso 3315, Colonia La Calma C.P 45070, Guadalajara, Jalisco, Mexico \\ ${ }^{2}$ Private practice, Av. Prof. Othon Gama D'eça, 677, Ed. The Office Avenida. Sala 703. Florianópolis, SC \\ ${ }^{3}$ Professor, Department of Prosthodontics, Federal University of Santa Catarina, Florianópolis, SC, Brazil \\ ${ }^{4}$ Associate Professor of the Discipline Periodontics, University of Tennessee Health Sciences College of Dentistry, \\ Memphis, TN, USA
}

Received: September 14, 2021; Accepted: September 25, 2021; Published: September 28, 2021

"Corresponding author: Cimara Fortes Ferreira, DDS, MSc, PhD - Associate Professor - Director of Implant Dentistry - Department of Prosthodontics University of Tennessee School of Dentistry - Dunn Dental Building - 875 Union Avenue - Memphis,TN 38163,Tel. No: (901) 448-4494; Fax. No: (901) 448-6751; , E-mail: cimarafortes@hotmail.com

\begin{abstract}
Background: The implant-abutment micro-gap has been investigated as a potential etiological factor for peri-implant diseases.

Purpose: The aim of this study was to determine the marginal accuracy of different zirconia CAD/CAM abutments placed on external hex implants.

Materials \& methods: Twelve external hex implants $(4.1 \mathrm{~mm})$ were used from the same company. The samples were divided into four groups: group 1) $4 \mathrm{~mm}$ diameter anti-rotational (AR) stock titanium abutments ( $\mathrm{n}=4$ ); group 2) scanned (3Series, Dental Wings) and milled (RCS-1, Röders GmbH) $4 \mathrm{~mm}$ diameter zirconiaabutments ( $\mathrm{n}=4$ ); group 3) scanned (3Series, Dental Wings) and milled (CNC 240, Lava) $4 \mathrm{~mm}$ diameterzirconia abutments ( $\mathrm{n}=4)$; and, group 4) two piece $4.1 \mathrm{~mm}$ diameter stock abutments (Ti-base, CEREC, Sirona) ( $\mathrm{n}=4)$, and torqued according with the manufacturer's instructions $(30 \mathrm{Ncm}, 20 \mathrm{Ncm}, 20 \mathrm{Ncm} \& 35 \mathrm{Ncm}$, respectively). The samples were placed in a sample holder and segmented longitudinally. The implant-abutment gap was measured in 6 different pre-determined locations using optic microscopy. Results: One-way ANOVA statistical analysis was conducted and showed that the micro-gaps in the group 1 samples were not significantly different when compared with the micro-gaps in group 4 samples. However, a significant difference $(\mathrm{p}<0.05)$ was found between the micro-gaps when using titanium abutments (groups $1 \& 4)$ compared to zirconia abutments (group 3).

Conclusion: Within the limits of this study, it was concluded that zirconia abutments cannot be milled with the same degree of precision as the metal abutments. The mechanical effects of marginal implant-abutment microgap and risk of microbial infiltration should be evaluated in clinical investigations.
\end{abstract}

Keywords: Dental implant; Abutment interface;Microleakage.

\section{Introduction}

Peri-implant diseasesare currently not well understood, and they occur despite the high success rates of dental implant prostheses[1-4]. The presence of a micro-gap between the implant and the abutment has been investigated as a possible etiological factor for peri-implant diseases [5]. The micro-gap is defined as a micro space between the implant and the abutment intereface [6,7]. This interface is generally at the micron level and is located at the alveolar crest in implants with external hex connections. This micro-gap functions as a niche for bacteria that release inflammatory cytokines in the surrounding hard and soft tissues [8-10].

The bidirectional microleakage (from the inner part of the implant to the outer part of the implant and vice-versa) has been reported in several dental implant systems with different types of abutments [11-17]. In addition, based on various in vitro and in vivo studies, microleakage plays an important role in bacterial growth and peri-implant pathogenesis [18,19].

The microleakage decreases significantly with a 10 to $20 \mathrm{Ncm}$ abutment torque increase above the value recommended by the manufacturer [20]. However, it is important to note that the incremental abutment screw torques results in a progressive decrease in the removal torques [21,22]. The zirconia abutments (ZiA) have become the abutment of choice, especially with increased aesthetic demands in patients with thin soft tissue biotype. Moreover, these posts are generally placed at a lower torque than the manufacturer recommends due to its high risk of fracture [23].

Currently, there are available CAD/CAM milled one or two-piece zirconia abutments. The one piece abutments are completely 
milled at a central production process by CAD/CAM technology, including the connection of the abutment to the implant. The twopiece abutment (hybrid abutments) consist of a stock titanium base on which a CAD/CAM milled Zirconia or lithium dissilicate coping is cemented [24]. The aim of this study was to compare the vertical marginal precision of prefabricated titanium and milled zirconia abutments placed on external hex implants.

\section{Materials and Methods}

Twelve external hex Easy Grip implants (prosthesis System Connection Ltd., São Paulo, Brazil), 10mm height and $4.0 \mathrm{~mm}$ in diameter, were used in this study. Twelve specific abutments were used for this type of implants: group 1) Group positive control, stock titanium abutment (ConexãoSistemas de PróteseLtda, São Paulo, Brazil); group 2) zirconia abutment, scanned in Dental Wings and milled in milling Röders; Group 3) zirconia abutment, scanned in Dental Wings and milled in Lava (3M ESPE Dental Products, Ontario, Canada); and, group 4) two-piece Ti abutment base (Sirona), scanned and milled in CEREC (Sirona Dental Systems, Bensheim, Germany).

Zirconia abutment platforms (part of the external hexagon) were scanned three-dimensionally on the implant analog. The zirconia abutments were prepared according with the shrinkage indicated by the manufacturers. The 16 abutments were tightened to 16 randomly selected implants.

Equal lengths of the catalyst paste and the base of the light silicone paste Imprint II Garant (3M ESPE Dental Products 2510 Conway Avenue, St. Paul, MN) were dispensed on a glass plate and mixed according with the manufacturer's recommendations. The mixed silicone was immediately placed on the implant platform and the abutment was seated and screwed to the implant. The abutments were fixed to the implants by tightening the connecting prosthetic screw by means of a torque wrench. The abutment placement torque was $20 \mathrm{Ncm}$ in zirconia abutments, $30 \mathrm{~N}$ on the stock titanium abutments and $35 \mathrm{Ncm}$ in the Ti-base abutments. All abutments were placed following the manufacturer's recommendation.

After the setting time elapsed, the excess silicone was cut with no. 15 scalpel blade (Solidor. Kyuan Suzhou Medical App. Co. Ltd China). The scalpel blade was replaced by a new one every 3 abutments to avoid tearing of the silicone addition.

The implant-abutment assembly was included in acrylic resin. After inclusion, each set was identified with numbers and letters of the alphabet (A to D). Samples were placed in a sample port and segmented through the long axis in a precision cutting machine (Isomet 4000 Linear Precision Saw, Buhler). The cutting speed used was $3000 \mathrm{rpm}$ with a $1.2 \mathrm{~mm} / \mathrm{s}$ feed rate under profuse cooling water.

The samples were sanded to reduce the processing marks left on the cutting interface. Sandpaper was used from the coarser to the finer grain grades (grain size 320, 400, 600 and 1200) are using an automatic sander (AROTEC AROPOL 2V, AROTEC). Each sandpaper particle size was used for 30 seconds for sanding the specimens under profuse water irrigation. Every 3 sets the abrasive silicon carbide was replaced by a new one to avoid failure during grinding. Polishing was not carried out in order to preserve most of the silicone between the implant and the abutment.

Special precautions were taken in order to minimize the angle of the sample, not to produce distortion in the gap region. These precautions included: applying a uniform pressure over the entire surface of the sample and properly positioning the sample (long axis perpendicular to the assembly direction of the disk) during the cutting procedures. A thorough washing was performed between each step, the specimens were cleaned in water and immersed in an ultrasonic tank using liquid soap.

The final samples were mounted in parallel with the table measuring microscope (Leica DM 4000, Wetzlar, Germany) to measure in two areas of adjustment to internal adaptation (100 $\mathrm{x}$ magnification). A series of optical micrographs were acquired throughout the length of the implant-abutment interface region. The micrographs were analyzed using the software (LAS Image Analysis, Leica Microsystems, Buffalo Grove, IL, USA) and the implant-abutment micro-gap measurements were made throughout the interfacial aspect. The interface micro-gap was evaluated by calculating the spaces between the abutment and the dental implant. The implant-abutment micro-gap was measured from 6 different locations for each implant-abutment assembly by means of optic microscopy. The outermost point on the left image is designated as a measuring point (Figure 1).

The procedure was performed on all samples and the same image acquisition and analysis were performed for each section along the implant-abutment micro-gap for each sample.

\section{Results}

Note the implant sections obtained through the experimental method showed adequate exposure of the regions evaluated in all sectional sets (Figure 2). General Observations (100x magnification) showed the presence of a micro-gaps between the implant and abutment in all samples, and communication between the internal and external connection in some regions (Figure 3). Following micrograph (Figure 2), the implant-abutment microgaps were easily measured by computer software (LAS Image Analysis, Leica Microsystems, Buffalo Grove, IL, USA). There was no evidence of sample distortion and the sample angulation was minimal.

The results of the analysis of variance showed that the micro-gap sizes in group 1 were not significantly different than the values seen in group 4 . However, a significant difference $(p<0.05)$ was found between the micro-gaps of titanium abutments (groups 1 and 4) compared to zirconia abutments (group 3). 

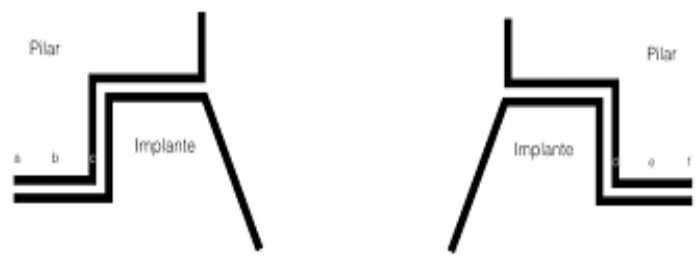

Figure 1: Schematic image showing the six measurements $(a, b, c, d, e, f)$ taken from the implant to the abutment.

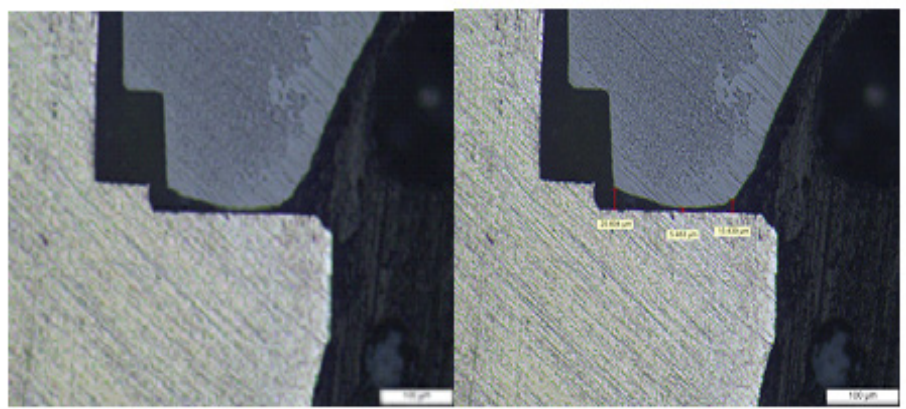

Figure 2: Microscopic image (100x magnification) showing implant-abutment microgap measurements taken by means of a software (LAS Image Analysis, Leica Microsystems, Buffalo Grove, IL, USA).
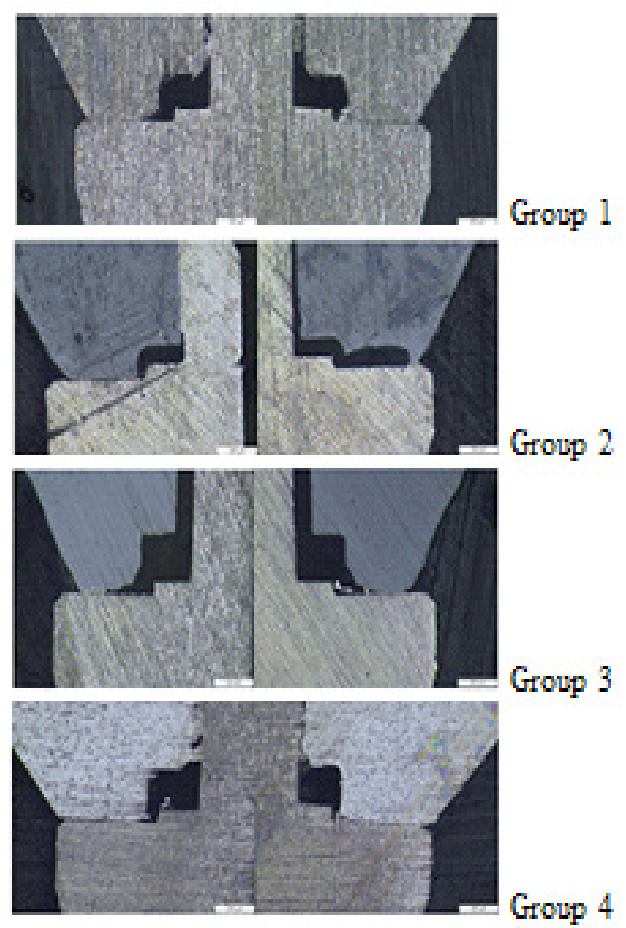

Figure 3: Microscopic image (100x magnification) showing sections taken of the implant-abutment interface of groups 1-4.

Citation: Jair Rodríguez-Ivich, Abraão Moratelli Prado, Antônio Carlos Cardoso, Cimara Fortes Ferreira. (2021) Analysis of the Titanium-Zirconia Implant-Abutment Micro-Gaps. J Dent Oral Disord Ther 9(2): 1-6 DOI: http://dx.doi.org/10.15226/ 


\section{Discussion}

Based on the phenomenon of Osseo integration, the dental implant based rehabilitations are a highly successful treatment modality in private practice [25-28]. While the post-surgical bone height is somewhat predictable, the crestal bone maintenance is subject to both; mechanical and microbiological factors related to the implant-abutment interface [29-41]. The magnitude of the abutment-implant gap has received significant attentionand different methods have been used for these investigations [14,34,42-46].

General observation of implant-abutment sections showed that a micro-gap exists for all implants (Figure 2). The presence of a gap across the region where the implant and abutment should theoretically be in contact can compromise the short-term treatment success due to mechanical overload, screw loosening during function, and acute or chronic inflammation of the periimplant tissues [47-52].

A technique that accurately measures the abutment-implant micro-gap was developed in order to determine differences in the four implant-abutment groups and between specific locations within each sample.

Zirconia abutments are machined before sintering, which results in approximately $20 \%$ to $25 \%$ ceramic shrinkage [53,54]. Thus, the sintering process can increase the resulting micro-gap when using ceramic abutment. Although zirconia has been shown to have lower risk of bacterial colonization when compared to titanium, the increased micro-gaps shown with the use of zirconia abutments can increase the probability of bacterial colonization, when compared to that observed with metal abutments $[55,56]$.

Different marginal adaptations of one-piece ceramic abutments were found in the present study. The scanned abutments processing is different for each abutment brand, resulting in specific abutments sizes. Thus, the results of the present study may have been a result of both different percentages of shrinkage and scanning techniques and milling related to the brand Specifically machined abutments with All Wings system showed better adaptation than those machined with 3Shape system.

The explanation of the existence of a micro-gap on the implantabutment interface includes; inaccurate machining of the implant parts, excessive torque during placement of the abutment leading to distortion, improper adjustment of the male-female hex, among others. Taking into account the careful adaptation and torque applied to implants in the present study, the presence of the implant-abutment micro-gap was probably due to imprecise machining of the internal abutment hex for the implant system used. In addition to the zirconia shrinkage that occurs during sintering [53].

\section{Conclusion}

The technique described in the present study provides a broader view of the interface adaptation that exists between four different prosthetic abutments and external hex implants.

Within the limits of this study, it was shown that the zirconia abutments cannot be milled with the same degree of accuracy as the metallic abutments. The control group configuration, which featured a titanium abutment attached to a titanium implant, and the metal link group (TiBase) showed the smallest implantabutment interface microgap.

One-piece zirconia abutment misfits can cause screw loosening, increase in the micro-gap size, and marginal bacterial infiltration. Therefore, the use of titanium or of a titanium "metallic link" in zirconia, may promote a smaller interface micro-gap, which may prevent mechanical problems. It is concluded that CAD-CAM milled abutments require further refinement. The mechanical effects of marginal implant-abutment micro-gap and risk of microbial filtration should be evaluated in clinical investigations.

\section{Acknowledgment}

The materials used in this study were donated by Conexao Prosthesis System Ltda, São Paulo, Brazil.

\section{References}

1. Adell R, Lekholm U, Rockler B. A 15 yearstudy of osseointegratedimplants in thetreatment of theedentulousjaw. Int J Oral Surg. 1981;10:387-416.

2. Adell R, Eriksson B, Lekholm U, Branemark PI, Jemt T. Long termfollow up study of osseointegratedimplants in treatment of totallyedentulousjaw. Int J Oral MaxillofacImplants. 1990;5:347-359.

3. Albrektsson T, Zarb GA, Worthington P, Eriksson AR. Thelongtermefficacy of currentlyused dental implants: a review and proposedcriteria of success. Int J OralMaxillofacImplants. 1986;1:1125.

4. Albrektsson T. Onlong-termmaintenance of osseointegrated response. AustProsthodont J. 1993;7(Suppl):15-24.

5. Quirynen M, Van Steenberghe D. Bacterialcolonization of theinternalpart of twostageimplants.An in vivo study. Clin Oral Implants Res. 1993;4:158-161.

6. Esposito M, Hirsch JM, Lekholm U, Thomsen P. Biologicalfactorscontributingfailures of osseointegrated oral implants (I) Successcriteria and epidemiology. Eur J Oral Sci. 1998;106:527551.

7. Aloise JP, Curcio R, Laporta MZ, Rossi L, Silva AM, Rapoport A. Microbialleakagethroughtheimplantabutment interface of morse taperimplant in vitro. Clin Oral Implants Res. 2010;21:328-335.

8. Zambon JJ. Periodontal diseases: microbialfactors. Ann Periodontol. 1996;1:879-925.

9. Berglundh T, Lindhe J,Marinello C, Ericsson I, Liljenberg B. Softtissuereactionto de novo plaque formationonimplants and teeth. An experimental study in thedog. Clin Oral Implants Res. 1992;3:1-8. 10. Orsini G, Fanali S, Scarano A, Petrone G, Silvestro S, Piattelli A. 
Tissuereaction, fluids and bacterialinfiltration in implantsretrieved at autopsy: a case report. Int J Oral MaxillofacImplants. 2000;15:283286.

11. Jansen VK, Conrads G, Jurgen R. Microbialleakage and marginal fit of theimplant-abutment interface. Int J Oral MaxillofacImplants. 1997;12:527-540.

12. Persson LG, Lekholm U, Leonhardt A, Dahlen G, Lindhe J. Bacterialcolonizationontheinternalsurfaces of Branemarksystemimplantcomponents. Clin Oral Implants Res. 1996;7:90-95.

13. Guindy JS, Besimo CE, Besimo R, SchielH,Meyer J. Bacterialleakageinto and fromprefabricatedscrew-retainedimplant-borne crowns in vitro. J Oral Rehabil. 1998;25:403-408.

14. Dibart S, Warbington M, Su FM, Skobe Z. In vitro evaluation of implant-abutmentbacterialseal: thelockingtapersystem. Int J Oral MaxillofacImplants. 2005;20:732-737.

15. Steinebrunner L, Wolfart S, Bobbman K, Kern M. In vitro evaluation of bacterialleakagealongtheimplant-abutment interface of differentimplantsystems. Int J Oral MaxillofacImplants. 2005;20:875881.

16. Broggini N, Mc Manus LM, Hermann HS. Peri-implantinflammationde finedbytheimplant-abutment interface. J Dent Res. 2006;85:473-478.

17. Nascimento C, Barbosa RE, Issa JP, Watanabe E, Ito IY, Albuquerque RF Jr. Bacterialleakagealongtheimplantabutment interface of premachinedorcastcomponents. Int J Oral MaxillofacSurg. 2008;37:177-180.

18. Broggini N, Mc Manus LM, Hermann HS. Peri-implantinflammationde finedbytheimplant-abutment interface. J Dent Res. 2006;85:473-478.

19. Hermann JS, Schoolfield JD, Schenk RK, Buser D, Cochran DL. Influence of thesize of microgaponcrestalbonechangesaroundtitaniumimplants. A histometricevaluation of unloaded non-submergedimplants in thecaninemandible. J Periodontol. 2001;72:1372-1383.

20. Harder S, Dimaczek B, Acil Y, Terheyden H, Wolf S, Kern M. Molecular leakage at implant-abutmentconnection- In vitro investigation of tightness of internalconicalimplant-abutmentconnectionsagainstend otoxinpenetration. Clin Oral Investig. 2009;14:427-432.

21. Besimo CE, Guindy JS, Lewetag D, Meyer J. Prevention of bacterialleakageinto and fromprefabricatedscrewretainedcrownsonimplants in vitro. Int J Oral MaxillofacImplants. 1999;14:654-660.

22. Weiss EI, Kozak D, Gross MD. Effect of repeatedclosuresonopening torque values in sevenabutment-implantsystems. J ProsthetDent. 2000;84:194-199.

23. Sailer I, Sailer T, Stawarczyk B, Jung RE, Hammerle CH. In vitro study of theinfluence of thetype of connectiononthe fracture load of zirconiaabutmentswithinternal and externalimplantabutmentconnections. Int J Oral MaxillofacImplants. 2009;24:850858.

24. Gehrke P, Alius J, Fischer C, Erdelt KJ, Beuer F. Retentivestrength of two-piece CAD/CAM zirconiaimplantabutments. Clin ImplantDentRelat Res.2014;16:920-925.

25. Branemark PI, Adell R, Breine U, Hansson BO, Lindstrom J, Ohlsson A. Intra-osseousanchorage of dental prostheses. I. Experimental studies.
Scand J PlastReconstrSurg. 1969;3:81-100.

26. Branemark PI, Hansson BO, Adell R. Osseointegratedimplants in thetreatment of theedentulousjaw. Experiencefrom a 10-year period. Scand J PlastReconstrSurgSuppl. 1977;16:1-132.

27. Broggini N, McManus LM, Hermann JS. Persistentacuteinflammation at theimplant-abutment interface. J Dent Res. 2003;82:232-237.

28. Rimondini L, Marin C, Brunella F, Fini M. Internalcontamination of a 2-component implantsystemafterocclusalloading and provisionallylutedreconstructionwithorwithout a washerdevice. J Periodontol. 2001;72:1652-1657.

29. McGlumphy EA, Mendel DA, Holloway JA. Implantscrewmechanics. Dent Clin North Am. 1998;42:71-89.

30. Jorneus L, Jemt T, Carlsson L. Loads and designs of screwjointsfor single crownssupportedbyosseointegratedimplants. Int J Oral MaxillofacImplants. 1992;7:353-359.

31. Patterson EA, Johns RB. Theoreticalanalysis of the fatigue life of fixturescrews in osseointegrated dental implants. Int J Oral MaxillofacImplants. 1992;7:26-33.

32. Adell R, Lekholm U, Rockler B. Marginal tissuereactions at osseointegratedtitaniumfixtures (I). A 3-year longitudinal prospectivestudy. Int J Oral MaxillofacSurg. 1986;15:39-52.

33. Broggini N, McManus LM, Hermann JS. Persistentacuteinflammation at theimplant-abutment interface. J Dent Res. 2003;82:232-237.

34. Becker W, Becker BE, Newman MG, Nyman S. [Clinical and microbiologicalfindings, that can cause failure of dental implants]. Quintessenz. 1991;42:9-21.

35. Lang NP, Bragger U, Walther D, Beamer B, Kornman KS. Ligatureinduced peri-implantinfection in cynomolgusmonkeys. I. Clinical and radiographicfindings. Clin Oral Implants Res. 1993;4:2-11.

36. Mombelli A, Marxer M, Gaberthuel T, Grunder U, Lang NP. Themicrobiota of osseointegratedimplants in patientswith a history of periodontal disease. J Clin Periodontol. 1995;22:124-130.

37. Quirynen M, OpHeij DG, Adriansens A, Opdebeeck HM, van Steenberghe D. Periodontal health of orthodonticallyextrudedimpactedteeth. A split-mouth, longtermclinicalevaluation. J Periodontol. 2000;71:1708-1714.

38. Quirynen M, Papaioannou W, van Steenberghe D. Intraoraltransmission and thecolonization of oral hardsurfaces. J Periodontol. 1996;67:986-993.

39. Tonetti MS. Riskfactorsforosseodisintegration. Periodontol 2000. 1998;17:55-62.

40. Bozkaya D, Muftu S. Mechanics of thetaperedinterferencefit in dental implants. J Biomech. 2003;36:1649-1658.

41. Quirynen M, De Soete M, van Steenberghe D. Infectiousrisksfor oral implants: a review of theliterature. Clin Oral Implants Res. 2002;13:1-19.

42. Binon PP. Theeffect of implant/abutment hexagonal misfitonscrewjointstability. Int J Prosthodont. 1996;9:149-160.

43. Binon PP. Evaluation of theeffectiveness of a techniquetopreventscrewloosening. J ProsthetDent. 1998;79:430432.

44. Turki LE, Chai J, Lautenschlager EP, Hutten MC. Changes in prostheticscrewstabilitybecause of misfit of implantsupportedprostheses. Int J Prosthodont. 2002;15:38-42. 
45. Khraisat A, Stegaroiu R, Nomura S, Miyakawa O. Fatigue resistance of twoimplant/abutmentjointdesigns. J ProsthetDent. 2002;88: 604-610.

46. Khraisat A, Hashimoto A, Nomura S, Miyakawa O. Effect of lateral cyclicloadingonabutmentscrewloosening of anexternalhexagonimplantsystem. J ProsthetDent. 2004;91:326-334.

47. Lee KH, Maiden MF, Tanner AC, Weber HP. Microbiota of successfulosseointegrated dental implants. J Periodontol. 1999;70:131-138.

48. Piattelli A, Vrespa G, Petrone G, Iezzi G, Annibali S, Scarano A. Role of themicrogapbetweenimplant and abutment: a retrospectivehistologicevaluation in monkeys. J Periodontol. 2003;74:346-352.

49. Lang NP, Bragger U, Walther D, Beamer B, Kornman KS. Ligatureinduced peri-implantinfection in cynomolgusmonkeys. I. Clinical and radiographicfindings. Clin Oral Implants Res. 1993;4:2-11.

50. BickfordJr J. AnIntroductiontotheDesign and Behavior of BoltedJoints. New York: Marcel Decker. 1981:528-542.
51. Broggini N, McManus LM, Hermann JS. Peri-implantinflammationdefi nedbytheimplant-abutmentinterface. J Dent Res. 2006;85:473-478.

52. Jansen VK, Conrads G, Richter EJ. Microbialleakage and marginal fit of theimplant-abutment interface. Int J Oral MaxillofacImplants. 1997; 12:527-540.

53. Oh GJ, Yun KD, Lee KM, Lim HP, Park SW. Sinteringbehavior and mechanicalproperties of zirconia compacts fabricatedbyuniaxialpressforming. J AdvProsthodont. 2010;2:81-87.

54. Raidgrodski AJ. Contemporaryall-ceramicfixedpartialdentures: A review. Dent Clin North Am. 2004;48:531-544.

55. Rimondini L, Cerroni L, Carrassi A, Torricelli P. Bacterialcolonization of zirconiaceramicsurfaces: An in vitro and in vivo study. Int J Oral MaxillofacImplants. 2002;17:793-798.

56. Scarano A, Piattelli M, Caputi S, Favero GA, Piattelli A. Bacterialadhesiononcommerciallypuretitanium and zirconium oxide disks: an in vivo human study. J Periodontol. 2004;75:292-296. 